\title{
Editorial
}

\section{The Stars are Aligned: Nurses Must Exercise Their Voice}

\section{As estrelas estão alinhadas: As enfermeiras devem exercer a sua voz}

\section{Las Estrellas están alineadas: Las Enfermeras deben ejercer su Voz}

Afaf I. Meleis

PhD, DrPS(hon), FAAN. Professor of Nursing and Sociology. University of Pennsylvania School of Nursing. Doctora Honoris Causa por la Universidad de Alicante (España).

Cómo citar esta editorial en edición digital: Meleis, A.I. (2015). The Stars are Aligned: Nurses Must Exercise Their Voice. Cultura de los Cuidados (Edición digital) 19, 42.

Disponible en: http://dx.doi.org/10.14198/cuid.2015.42.01>

Correspondencia: Room 418 Fagin Hall. 418 Curie Blvd. Philadelphia, Pennsylvania 19104-4217

UNITED STATES

Correo electrónico: email: meleis@nursing.upenn.edu.

Editorial recibida por gentileza de la autora.

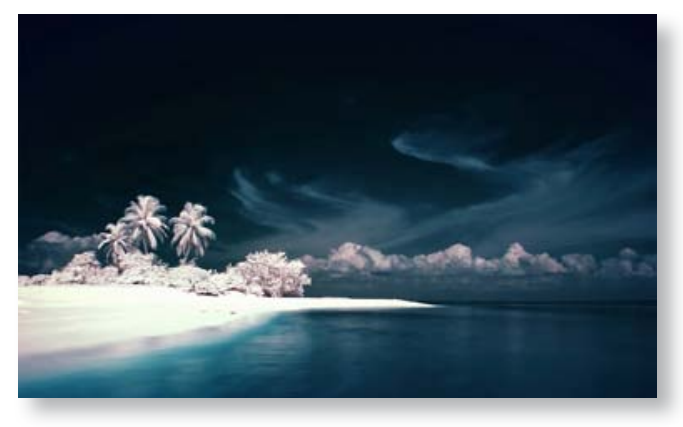

ABSTRACT

The author develops in this editorial a claiming discourse whose purpose is to draw attention to the nurses to make their voices heard at a particularly propitious time for it (the stars are aligned). Afaf Meleis describes the current situation as the ideal for the nursing profession, finally, exercise your voice and contribute to optimizer health care through greater presence of nursing in all areas related to health. Demographic, educational, social and health changes, increasingly require the presence of nurses to optimize the quality of care, especially self-care.

Keywords: Nurses, self-care, nurse voice, presence of nurses in health systems.

\section{RESUMO}

O autor desenvolve neste editorial discurso um vingativo cujo objetivo é chamar a atenção para os enfermeiros para fazer suas vozes ouvidas em um momento particularmente propício para isso (as estrelas estão alinhadas). Afaf Meleis descreve a situação atual como o ideal para a profissão de enfermagem, finalmente, exercer a sua voz e contribuir para o otimizador de cuidados de saúde através de uma maior presença de enfermagem em todas as áreas relacionadas com a saúde. „, Mudanças sociais e demográficas de educação em saúde, cada vez mais exigem a presença de enfermeiros para otimizar a qualidade dos cuidados, especialmente auto-cuidado.

Palavras-chave: Enfermeiros, auto-cuidado, enfermeira de voz, presença de enfermeiros nos sistemas de saúde.

\section{RESUMEN}

La autora desarrolla en esta editorial un discurso reivincativo cuyo propósito es llamar la atención a los profesionales de enfermería para que hagan oír sus voces en un momento espe- 
cialmente propicio para ello (las estrellas están alineadas). Afaf Meleis describe la situación actual como la idónea para que el colectivo enfermero, por fin, ejercite su voz y contribuya a optimizer los cuidados de salud mediante una mayor presencia de la enfermería en todos los ámbitos relacionados con la salud. Los cambios demográficos, educativos, sociales y de salud, requieren cada vez más la presencia de las enfermeras para optimizar la calidad de los cuidados, especialmente de los autocuidados.

Palabras clave: Enfermeras, autocuidados, voz enfermera, presencia de enfermeras en sistemas de salud.

This is the best time for nurses to make an impact on health care policies that would empower us, and that could result in providing equitable, quality care. This is the best time for nurses to have a strong, meaningful voice in developing and in supporting policies that increase patient and family access to quality health care by promoting self-care, preventing diseases and championing wellbeing. Why do I think it is the best time? Here are some reasons.

Nursing education has come of age, joining other well-established disciplines that are offered in distinguished universities around the world. While there are some countries still lagging in offering nursing education at the university level, many countries have acknowledged the need for nurses to be well educated along side other health professionals. Providing nurses with university education prepares them to have an equal voice in a team of providers. Higher levels of nursing education also allow them the privilege of educational mobility that is based on knowledge. Educational mobility promotes career mobility and opportunities for leadership. Leadership po- sitions enhance opportunities for nurses to affect health care policies which in turn could improve health care delivery, particularly for vulnerable and marginalized populations, a group that nurses have always cared for and about. Better education empowers nurses.

Scholarship in nursing is reflected in the development of research centers and research programs, the results of which have influenced countless policies. Examples include researching symptom management that resulted in modifying strategies for pain management; more effective nurse staffing patterns that resulted in reducing hospital morbidity and mortality and providing transitional care in hospitals and in nursing homes which resulted in better outcomes and less hospitalization; allowing family members to be present in emergency and in intensive care departments to support and advocate for patients; allowing the use of animals to promote healing in their owners; and regulating sedatives in children with acute care issues and supporting more appropriate levels of treatments. These are but a few examples of how nursing scholarship helps transform health care policies.

It is also the perfect time for nurses to make an impact because of major recommendations that resulted from national and international reports related to nursing and quality care. The fact that some countries saw to it to appoint task forces to study the nursing situation and to make recommendations for changes in nursing scope of practice, education and care reflect the acknowledgement of the value of nursing in national health care system priorities. Examples are the Future of Nursing Report for reform in U.S. nursing ${ }^{1}$ and The Lancet Commission appointed in the United Kingdom to study nursing situations and to propose recommendations to improve nursing care and celebrate 
higher education. ${ }^{2}$ All the recommendations suggest better education for nurses and more support for scope of practice that is more congruent with nurses' abilities and capabilities.

Another indication that the stars are aligned is reflected in the recommendations advocated by the global Lancet Report, "Health professionals for a new century: transforming education to strengthen health systems in an interdependent world." 3 This futuristic report was based on the study of existing educational models in nursing, medicine and in public health programs which were deemed to need updating and to make education more responsive to global health needs. The recommendations call for providing interprofessional education based on a framework of equity and justice, one that respects global advances in knowledge, local health priorities and uses innovative structures utilizing more futuristic teaching and learning modalities. The report recommends that educational models must benefit from more advanced technology and new models of communication, as well as making education more dynamic and flexible. Implementing these recommendations requires collaboration between ministries of health and education, private and public sectors, as well as requiring collaborative, innovative funding sources. Nurses who base their education models on health and wellness, on individualized care, on community based partnerships and on interdisciplinary roles, can co-lead in implementing these recommendations.

The nature of demographic changes and health issues also places nurses in the forefront. Global migration and immigration patterns and the increase in aging populations have pointed to lifestyle changes that require self care and community based care. In many countries nurses have already been the home care nurses and the visiting nurses in communities. Nurses are already primed experts when it comes to many of the skills they have acquired as caregivers for lifestyle changes. They have created and implemented many innovative practice models for promotion of health and wellbeing which can be used by other health care team members. Nurses can lead the way, as they already have the experience in implementing, testing and evaluating these models of care. They have been proactive in representing the perceptions and the capabilities of populations' self-care abilities; hence they can influence the rest of health care teams.

University level education, research findings that translate to best evidence based practices, national and international credible reports that value nursing contributions and the many global policy recommendations for effective utilization of nursing capacities, as well as the many demographic and health care changes that require nursing expertise, all put nurses in the best possible positions to co-lead health care reform and to ensure the provision of equitable, quality care.

The stars are aligned for nurses to make a major difference. Now is the time for nurses to raise their voices, lead and impact the future of health care globally.

\footnotetext{
${ }^{1}$ IOM (Institute of Medicine). 2011. The Future of Nursing: Leading Change, Advancing Health. Washington, DC: The National Academies Press.

${ }^{2}$ Aiken L, Azam Ali P, Benton D, Buchan J, Cowman A, Fawcett T, Finnegan A, Girvin J, Hayter M, McKee M, McKenna H, McIntosh I, Macleod Clark J, Rafferty AM (2014). The Lancet Commission on UK Nursing.

${ }^{3}$ Bhutta ZA, Chen L, Cohen J, Crisp N, Evans T, Fineberg H, Frenk J, Garcia P, Horton R, Ke Y, Kelley P, Kistnasamy B, Meleis A, Naylor D, Pablos-Mendez A, Reddy S, Scrimshaw S, Sepulveda J, Serwadda D, Zurayk H. (2010). Health professionals for a new century: transforming education to strengthen health systems in an interdependent world. The Lancet.
} 